Lingua Rima: Jurnal Pendidikan Bahasa dan Sastra Indonesia

Vol. 10 No. 1 Januari 2021

http://jurnal.umt.ac.id/index.php/lgrm

\title{
PENGGUNAAN WHATSAPP DAN GOOGLE FORM DALAM PEMBELAJARAN BAHASA INDONESIA DI SMK N 2 SEWON BANTUL
}

\author{
Akifee Bensulong ${ }^{1}$ \\ Universitas Ahmad Dahlan \\ Bewailing746748@gmail.com \\ Fitrian Nur Afifah ${ }^{2}$ \\ Universitas Ahmad Dahlan \\ Fitria25nur@gmail.com \\ Isna Zumrotus Solikhah ${ }^{3}$ \\ Universitas Ahmad Dahlan \\ Isna.Zumrotus13@gmail.com
}

\begin{abstract}
ABSTRAK
Tujuan penelitian ini yaitu penggunaan media sosial whatsapp dan aplikasi google form dalam pembelajaran Bahasa Indonesia di SMK. Penelitian ini merupakan kualitatif dengan metode analisis deskriptif. Adapun subjek penelitian ini merupakan siswa di SMK SMK Negeri 2 Sewon, Bantul dan SMK Negeri Bangunjiwo, Bantul. Teknik pengumpulan data observasi dan angket. Instrumen penelitian berkaitan dengan anget yaitu berkaitan dengan persepsi responden mengenai whatsapp dan google form serta kendalanya. Teknik analisis data dengan cara mengelompokkan jawaban siswa, dan menginterpretasikan jawaban siswa. Pembelajaran daring menggunakan whatsapp dan google form merupakan media paling efektif untuk proses pembelajaran. Hal tersebut terlihat pada faktor situasi kondisi siswa yang memiliki kesulitan jaringan internet. Selain itu, penggunaan google form pada pemberian evaluasi google form. Penggunaan google form sangat mudah dan efektif dengan keterbatasan kondisi siswa. Siswa masih dapat mengumpulkan tugas siswa walaupun koneksi internet terkendala.
\end{abstract}

Kata kunci: Whatsapp, Google form, pembelajaran pendidikan

\section{A. PENDAhuluan}

Dampak pandemik Covid-19 terjadi diberbagai bidang, salah satunya pendidikan. Perubahan metode mengajar pada masa pandemik Covid-19 harus dilakukan secara daring. Guru dan siswa melakukan proses belajar mengajar melalui metode jarak jauh. Hal ini mendatangkan dampak positif maupun negatif. Dampak positif yang ditimbulkan berkaitan dengan metode pembelajaran menjadi lebih variatif, siswa dapat lebih banyak mengeksplorasi pengetahuan melalui gawai, siswa lebih banyak waktu luang dengan keluarga, dan sebagainya. Namun, dampak negatif yang ditimbulkan yaitu pembelajaran jarak jauh mengurangi interaksi guru dan siswa, siswa lebih cepat bosan, guru tidak maksimal dalam menjelaskan, belum lagi koneksi jaringan yang buruk dan sebagainya. 


\section{Lingua Rima: Jurnal Pendidikan Bahasa dan Sastra Indonesia \\ Vol. 10 No. 1 Januari 2021 \\ http://jurnal.umt.ac.id/index.php/lgrm}

Oleh karena itu, guru harus selektif dan kreatif dalam memilih metode digunakan dalam pembelajaran agar siswa tidak merasa cepat bosan dalam menerima materi dan mengerjakan tugas. Peran guru sangat diperlukan, mereka harus tetap menjalankan tugas profesinya agar pembelajaran daring dapat berjalan secara maksimal. Selain metode, guru juga harus memilih media yang efektif dalam pembelajaran daring. Media pembelajaran yang digunakan dapat berupa aplikasi daring atau media sosial. Aplikasi daring dapat berupa google form, email, dan sebagainya. Media sosial yang dapat digunakan dalam pembelajaran daring misalnya whatsapp, facebook, instagram, youtube, dan sebagainya. Penggunaan aplikasi daring dan media sosial sangat membantu guru dalam melaksanakan pembelajaran daring.

Aplikasi google form dan media sosial whatsapp merupakan salah satu media pembelajaran daring yang efektif dan mudah digunakan. Aplikasi tersebut dapat digunakan dalam proses pembelajaran kapanpun dan dimanapun. Siswa dapat dengan mudah berinteraksi dengan guru menggunakan media sosial whatsapp group. Selain itu, guru juga dapat memantau perkembangan siswa melalui pengisian angket di google form. Penggunaan aplikasi dan media sosial ini merupakan inovasi pendidikan untuk menjawab tantangan akan ketersediaan sumber belajar yang lebih variatif. Keberhasilan dari suatu model ataupun media pembelajaran tergantung dari karakteristik peserta didiknya. Maka, peneliti tertarik untuk melakukan penelitian mengenai penggunaan media sosial whatsapp dan aplikasi google form dalam pembelajaran Bahasa Indonesia di SMK.

Penyajian e-learning bisa menjadi lebih interaktif. Informasi-informasi juga dapat disajikan secara up-to-date dan real-time. Begitu pula dengan komunikasinya, meskipun tidak dapat secara langsung tatap muka, tetapi forum diskusi perkuliahan dapat dilakukan secara online sehingga pembelajaran yang tidak terbatas dengan tempat dan waktu (time and place flexibelity) benar-benar terjadi (Prajana, 2017:124). Pembelajaran e-learning dapat menggunakan berbagai aplikasi dan media sosial. Peran media sosial dalam kegiatan belajar mengajar didalam kelas dan kita akan melihat secara langsung bagaimana penggunaan media sosial secara umum.

Keberadaan media sosial tidak lepas dai kegiatan akademik. Media komunikasi berperan sebagai sarana agar terwujud komunikasi yang efektif sehingga terjadi pembelajaran kondusif. Salah satu teknologi yang dijadikan media untuk berkomunikasi adalah WhatsApp atau yang bisa disingkaat dengan WA. Media sosial whatsapp merupakan teknologi Instant Messaging seperti SMS dengan berbantuan data internet berfitur 


\section{Lingua Rima: Jurnal Pendidikan Bahasa dan Sastra Indonesia \\ Vol. 10 No. 1 Januari 2021 \\ http://jurnal.umt.ac.id/index.php/lgrm}

pendukung yang lebih menarik. WhatsApp dipandang dapat menjadi media komunikasi akademik yang praktis dan efektif. Di dalam whatsApp terdapat bagai fungsi yaitu mengirim pesan pribadi, mengirim pesan group, mengirim foto, mengirim video, mengirim dokumen, bertelepon, video call, dan sebagainya. Namun, penggunaan media sosial tersebut tidak terlalu dimanfaatkan sebagai media literasi oleh siswa. Siswa hanya meluangkan waktu dengan WhatsApp sebagai media sosial sebatas berkirim pesan, foto maupun dokumen yang tidak memuat literasi sama sekali (Hutami, dan Nugraheni, 2020: 127).

Menurut Munawaroh (dalam Yensy, 2020:67 ) mengemukakan cara penggunaan media sosial whatsapp ini adalah peserta didik dapat berdiskusi dengan guru misalnya dengan mengirimkan hasil penyelesaian soal-soal latihan sesuai materi apabila ingin mengetahui benar atau salah dari hasil penyelesaian soal tersebut. Peserta didik dapat juga menanyakan permasalahan yang berkaitan dengan soal-soal latihan tersebut. Permasalahan yang ingin ditanyakan dapat dikirimkan di whatsapp group dengan terlebih dahulu mengambil gambar atau foto hasil penyelesaian soal latihan. Gambar atau foto yang dikirimkan dapat dilihat oleh seluruh anggota grup melalui smarthphone. Sehingga peserta didik yang lain dapat mencoba menyelesaikan atau menjawab permasalahan tersebut sebelum diselesaikan atau dijawab oleh guru.

Google form merupakan salah satu komponen layanan Google Docs. Aplikasi ini sangat cocok untuk mahasiswa, guru, dosen, pegawai kantor dan professional yang senang membuat quiz, form dan survey online. Fitur dari Google Form dapat di bagi ke orangorang secara terbuka atau khusus kepada pemilik akun Google dengan pilihan aksesibilitas, seperti: read only (hanya dapat membaca) atau editable (dapat mengedit dokumen). Selain itu, Google docs juga dapat menjadi alternatif bagi orang-orang yang tidak memiliki dana untuk membeli aplikasi berbayar untuk menggunakan program gratisan dibandingkan membajak program berbayar seperti Microsoft Office, karena kita tahu bahwa membajak program itu adalah tidak baik (Batubara, 2016:41-42)

\section{B. METODE PENELITIAN}

Penelitian ini merupakan kualitatif dengan metode analisis deskriptif. Adapun subjek penelitian ini merupakan siswa di SMK SMK Negeri 2 Sewon, Bantul dan SMK Negeri Bangunjiwo, Bantul. Teknik pengumpulan data observasi dan angket. peneliti mengumpulkan data-data lapangan dan memberikan angket yang berkaitan dengan pembelajaran bahasa Indonesia menggunakan media whatsapp dan google form. Data 
Lingua Rima: Jurnal Pendidikan Bahasa dan Sastra Indonesia

Vol. 10 No. 1 Januari 2021

http://jurnal.umt.ac.id/index.php/lgrm

diambil dengan angket yang diberikan kepada siswa berkaitan dengan respon siswa terhadap pembelajaran melalui whatsapp dan google form. Instrumen penelitian berkaitan dengan anget yaitu berkaitan dengan persepsi responden mengenai whatsapp dan google form serta kendalanya. Teknik analisis data dengan cara mengelompokkan jawaban siswa, dan menginterpretasikan jawaban siswa.

\section{HASIL PENELITIAN DAN PEMBAHASAN}

Pembelajaran daring adalah pembelajaran dimana dilakukan dengan cara virtual $\mathrm{Hal}$ ini terjadi dikarenakan pandemikk covid - 19 dimana sangat mempengaruhi proses pendidikan belajar mengajar sehingga dilakukan secara online yang diperlukan utama dalam pembelajaran yaitu jaringan internet. Dengan berbagai ragam situasi kondisi siswa maka dalam pembelajaran online dengan menyesuaikan situasi kondisi siswa yang paling efektif dilakukan di SMK Negeri 1 Bangunjiwo dan SMK Negeri 2 Sewon yaitu pembelajaran dilakukan menggunakan WhatsApp yang dilanjutkan dengan evaluasi pembelajaran dilakukan menggunakan Google Formulir. Hasil temuan penelitian ini dilakukan di SMK Negeri 2 Sewon, Bantul pada mata pelajaran Bahasa Indonesia menggunakan aplikasi diskusi whatsapp dalam proses pembelajaran. Proses evaluasi menggunakan google form yakni berupa penugasan kepada siswa setiap kali pertemuan. Penggunaan evaluasi google form untuk mengetahui tingkat kemampuan siswa ditingkat SMK sederajat. Hasil data dari penelitian evaluasi pembelajaran melalui google form yaitu sebagai berikut :

Tabel 1. Kehadiran dan Penilaian Tugas SMK N 2 Sewon Bantul

\begin{tabular}{|l|l|l|l|l|l|}
\hline \multirow{2}{*}{ Kelas } & \multirow{2}{*}{ Jumlah Siswa } & \multicolumn{5}{c|}{ Jumlah Siswa yang Mengerjakan Tugas } \\
\cline { 3 - 6 } & & $\mathbf{1}$ & $\mathbf{2}$ & $\mathbf{3}$ & $\mathbf{4}$ \\
\hline X tb 1 & 36 & 29 & 23 & 14 & 18 \\
\hline X tb2 & 36 & 28 & 13 & 14 & 12 \\
\hline XI kkbt 1 & 31 & 27 & 27 & 23 & - \\
\hline XI kkbt 2 & 32 & 21 & 22 & 22 & - \\
\hline
\end{tabular}

Proses pembelajaran daring dilakukan dengan menggunakan metode pembelajaran sesuai dengan kurikulum yang berlaku dengan menerapkan kurikulum baru bernama BDR (Belajar Dari Rumah) dimana ada perubahan RPP, indikator, media, bahan ajar, dsb yakni penyederhanaan kurikulum dalam rangka masa pandemikk covid - 19. Berdasarkan hasil penelitian, pembelajaran whatsapp dalam pembelajaran merupakan media / alat paling efektif untuk proses pembelajaran dengan berbagai faktor situasi kondisi siswa yang mana 


\section{Lingua Rima: Jurnal Pendidikan Bahasa dan Sastra Indonesia \\ Vol. 10 No. 1 Januari 2021 \\ http://jurnal.umt.ac.id/index.php/lgrm}

dilanjutkan dengan pemberian evaluasi google form merupakan aplikasi yang dapat digunakan sebagai evaluasi pembelajaran yang paling mudah dengan keterbatasan kondisi siswa. Namun terdapat berbagai kendala dalam pengumpulan tugas siswa yakni siswa menjadi tidak disiplin karena berbagai faktor sehingga siswa tidak mengerjakan tugas yang diberikan melalui google formulir. Hal ini terbukti dikarenakan berbagai alasan siswa yang mana pembelajaran secara daring merupakan pembelajaran secara tidak tatap muka, dan pengondisian siswa tidak terpantau secara langsung. Aplikasi ini merupakan media yang mudah digunakan namun tidak ada pembatasan waktu dsb sehingga sangat berpengaruh terhadap kedisiplinan dan tanggung jawab siswa sebagaimana menerapkan pendidikan karakter terhadap pembelajaran. Proses pembelajaran Pelaksanaan pembelajaran sudah pasti ada kelebihan dan kekurangan.

Setelah dilakukan penelitian terdapat dampak positif dan negatif media whatsapp dan google form dalam pembelajaran daring. Dampak positif media whatsapp dan google form dalam pembelajaran daring yaitu 1) pembelajaran dapat diakses dengan mudah yaitu melalui smartphone atau perangkat lain dan waktu belajar secara fleksibel dapat dilakukan dengan kesempatan kapan saja, 2) wawasan yang luas dengan metode konvensional dikarenakan menggunakan berbagai akses yang banyak dan diberikan kesempatan waktu yang banyak dalam mengakses pengetahuan, 3) biaya terjangkau dilakukan dirumah masing -masing tanpa menimbulkan faktor fisik yang diharuskan datang kesekolah, 4) adanya peluang siswa melakukan banyak pengembangan pengetahuan dan keterampilan diri dalam belajar, 5) banyak sekolah sekolah yang menggunakan literasi jaringan whatshapp dan google form dalam karena kemudahan dalam mengakses dan sedikit menghemat kuota dibandingkan menggunakan aplikasi lain.

Selain itu, dampak negatif penggunaan media whatsapp dan google form yang digunakan di SMK Negeri 2 Sewon, Bantul yaitu 1) keterbatasan akses internet dalam melakukan pembelajaran dan berkurangnya interaksi belajar dikarenakan jarak jauh sehingga hanya bisa melalui whatsapp dan google form,2) tidak bisa bertatap muka secara langsung sehingga suasana yang sangat berbeda dengan susahnya koordinasi siswa dan pemahaman terhadap materi / pemahaman komunikasi yang berbeda, 3) minimnya semangat belajar dengan alokasi waktu yang terkadang tidak sesuai, 4) sulit untuk mengontrol siswa yang serius mengikuti pelajaran dan yang tidak, 5) pembelajaran lebih banyak teoritis dibandingkan dengan praktik, 6) terbatasnya sarana media pembelajaran di dalam kelas teori untuk melaksanakan kegiatan belajar mengajar hambatan yang sering 


\section{Lingua Rima: Jurnal Pendidikan Bahasa dan Sastra Indonesia}

Vol. 10 No. 1 Januari 2021

http://jurnal.umt.ac.id/index.php/lgrm

dialami oleh siswa adalah keterbatasan sarana media pembelajaran di dalam kelas, 7) terganggu jaringan para siswa yang rumahnya di pegunungan atau didesa yang sulit untuk di jangkau.

Solusi yang diambil untuk mengatasi hal tersebut adalah 1) guru memaksimalkan menggunakan media yang ada yaitu dengan voice note dalam whatsapp dan memberikan handout sehingga peserta didik dapat mempelajari materi secara mandiri, 2) guru menggunakan media pembelajaran yang bervariasi untuk menarik minta siswa dalam belajar, 3) guru dapat menerapkan pembelajaran kelompok kecil maksimal 3 orang, agar siswa dapat saling berbagi pengetahuan, 4) guru dapat memberikan arahan langsung kepada siswa melalui whatsapp pribadi apabila ada kesulitan belajar.

\section{SIMPULAN DAN SARAN}

Pembelajaran dimana dilakukan dengan cara virtual atau dirumah masing - masing. Hal ini terjadi karena pandemik covid-19 yang sangat mempengaruhi proses pendidikan belajar mengajar. Maka, pembelajaran dilakukan secara daring. Pelaksanaan pembelajaran daring menyesuaikan situasi kondisi siswa. Pembelajaran Bahasa Indonesia daring dilakukan di SMK Negeri 2 Sewon menggunakan whatsapp dan google form. Pembelajaran daring menggunakan whatsapp dan google form merupakan media paling efektif untuk proses pembelajaran. Hal tersebut terlihat pada faktor situasi kondisi siswa yang memiliki kesulitan jaringan internet. Selain itu, penggunaan google form pada pemberian evaluasi google form. Penggunaan google form sangat mudah dan efektif dengan keterbatasan kondisi siswa. Siswa masih dapat mengumpulkan tugas siswa walaupun koneksi internet terkendala.

\section{E. DAFTAR PUSTAKA}

Batubara, H. H., 2016. Penggunaan Google Form Sebagai Alat Penilaian Kinerja Dosen di Prodi PGMI UNISKA Muhammadiyah Arsyad Al Banjari. Al Bidayah. Vol 8 No 1 PP $41-50$

Hutami, M. S., \& Nugraheni, A. S. 2020. Metode Pembelajaran Melalui Whatsapp Group Sebagai Antisipasi Penyebaran Covid-19 pada AUD di TK ABA Kleco Kotagede. PAUDIA. Vol 9 No 1 PP 126-130

Prajana, Andika. 2017. Pemanfaatan Aplikasi Whatsapp dalam media pembelajaran di UIN Ar-Raniry Banda Aceh. Jurnal Cyberspace. Vol 1 No 2 PP 122-133 